\title{
AQUATIC MOLLUSCS OF THE MREŽNICA RIVER
}

\begin{abstract}
LUBOŠ BERAN
Nature Conservation Agency of the Czech Republic, Regional Office Kokořínsko - Máchův kraj Protected Landscape Area Administration, Ceská 149, CZ-276 01 Mělník, Czech Republic (e-mail: lubos.beran@nature.cz)
\end{abstract}

\begin{abstract}
Beran, L.: Aquatic molluscs of the Mrežnica River. Nat. Croat. Vol. 28, No. 1., 99-106, Zagreb, 2019.

Results of a malacological survey of the Mrežnica River are presented. The molluscan assemblages of this river between the boundary of the Eugen Kvarternik military area and the inflow to the Korana River near Karlovac were studied from 2013 to 2018. Altogether 29 aquatic molluscs (19 gastropods, 10 bivalves) were found at 9 sites. Theodoxus danubialis, Esperiana esperi, Microcolpia daudebartii and Holandriana holandrii were dominant at most of the sites. The molluscan assemblages were very similar to assemblages documented during previous research into the Korana River. The populations of the endangered bivalves Unio crassus and Pseudanodonta complanata were recorded. An extensive population of another endangered gastropod Anisus vorticulus was found at one site. Physa acuta is the only non-native species confirmed in the Mrežnica River.
\end{abstract}

Key words: Mollusca, Unio crassus, Anisus vorticulus, Mrežnica, faunistic, Croatia

Beran, L.: Vodeni mekušci rijeke Mrežnice. Nat. Croat. Vol. 28, No. 1., 99-106, Zagreb, 2019.

U radu su predstavljeni rezultati malakološkog istraživanja rijeke Mrežnice. Sastav mekušaca ove rijeke proučavan je na području od Vojnog poligona Eugen Kvarternik do njenog utoka u Koranu blizu Karlovca, u razdoblju 2013. - 2018. ukupno je pronađeno 29 vrsta vodenih mekušaca (19 puževa, 10 školjkaša). Na većini lokaliteta dominirali su Theodoxus danubialis, Esperiana esperi, Microcolpia daudebartii i Holandriana holandrii. Sastav vrsta bio je vrlo sličan onom utvrđenom u prethodnom istraživanju rijeke Korane. Zabilježene su populacije ugroženih školjkaša Unio crassus i Pseudanodonta complanata. Na jednom od lokaliteta pronađena je veća populacija ugroženog puža Anisus vorticulus. Od alohtonih vrsta u ovom istraživanju rijeke Mrežnice potvrđena je jedino Physa acuta.

Ključne riječi: Mollusca, Unio crassus, Anisus vorticulus, Mrežnica, fauna, Hrvatska

\section{INTRODUCTION}

The Mrežnica River is the biggest tributary of the Korana River, situated in central Croatia, and belongs to the Danube River basin (Black Sea catchment area). In many karstic running waters of the Dinarid mountains freshwater molluscs are one of dominant macrobenthic groups and have an important role in the ecosystem of these rivers. Nevertheless, the aquatic molluscs of this river have not been investigated, while the freshwater molluscs of the Korana River were studied by the same author from 2009 to 2012 (BERAN, 2013). This research was continued with the survey of the Mrežnica River the results of which are presented here. 


\section{MATERIAL AND METHODS}

Data were obtained from field surveys conducted in the years 2013-2018. In total, 9 sites were studied (Fig. 1). The main sampling method for aquatic molluscs applied also for this research is washing vegetation or sediments using a metal sieve (diameter $20 \mathrm{~cm}, 0.8 \mathrm{~mm}$ mesh) combined with collection by hand, the surfaces of stones, wood and artificial materials (e.g. plastic bags and bottles) being examined. Diving (snorkelling) in shallow parts (ca to $3 \mathrm{~m}$ deep) was also used. Freshwater molluscs were determined using shell characteristics or dissected and then identified using their copulatory organs if identification based on shells alone was impossible. Specimens for dissection were killed in hot water and then fixed in $80 \%$ ethanol. Selected material of shells and killed specimens in $80 \%$ ethanol are deposited in the author's collection.

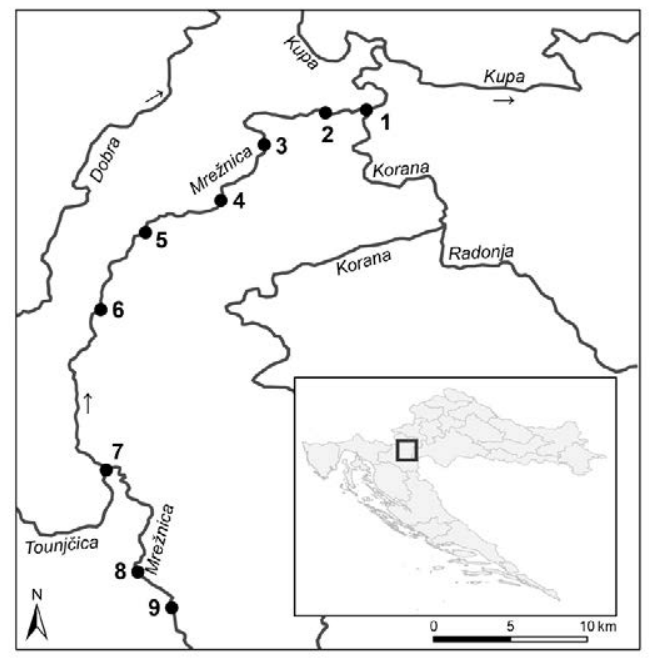

Fig. 1. The map of the Mrežnica River with the sites under study. Drawn by H. Medková.

\section{Study area}

The Mrežnica River is located in central Croatia. The river has a total length of $63 \mathrm{~km}$ and a watershed area of $64 \mathrm{~km}^{2}$. This river rises in Kordun, west of Slunj, and flows northwards, in parallel to the Korana, into which it flows near Karlovac. The river belongs to the Danube river basin. Like the Korana this river has a natural character at the most of its course. The Mrežnica is frequently overgrown with aquatic macrophytes and the river flow is interrupted with many waterfalls. The Tounjčica River is the biggest tributary of the Mrežnica.

\section{List of investigated sites}

Data in the list are as follows: site number, geographical co-ordinates, name of the nearest settlement, description of the site, date of investigation. Sites are depicted in Fig. 1. 
$1-45^{\circ} 27^{\prime} 56.5^{\prime \prime} \mathrm{N}, 15^{\circ} 33^{\prime} 54.2^{\prime \prime} \mathrm{E}$, Karlovac, the Mrežnica River at inflow to the Korana River, 17.8.2013;

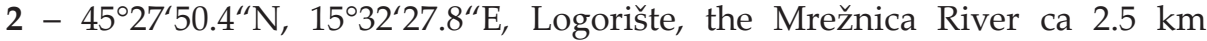
upstream of its confluence with the Korana River, 5.7.2014;
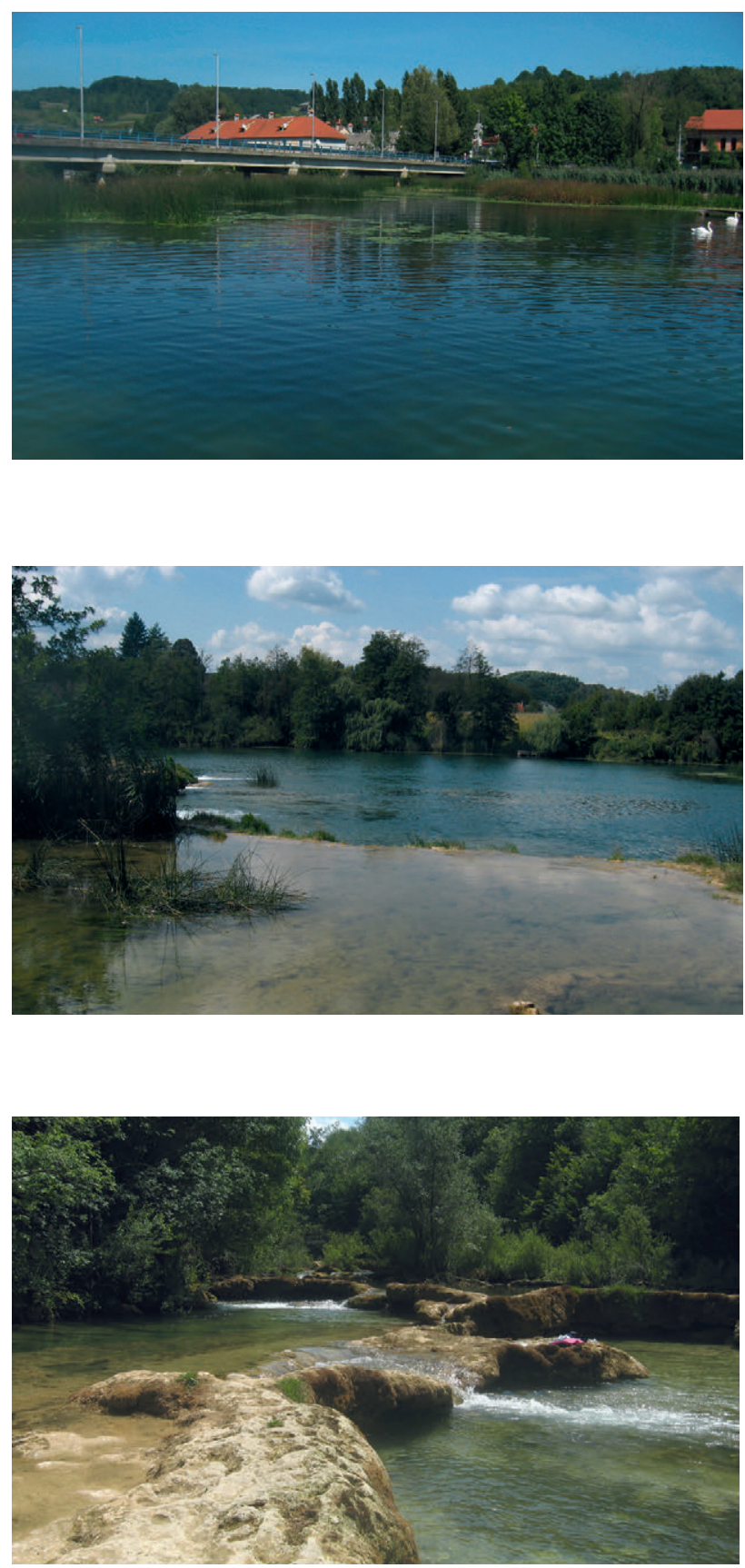

Fig. 2. The Mrežnica River in Duga Resa (site No. 3). All photos by the author.

Fig. 3. The Mrežnica River in Mrežnički Brig (site No. 4).

Fig. 4. The Mrežnica River near Primišlje (site No. 9). 
$3-45^{\circ} 26^{\prime} 43.1^{\prime \prime} \mathrm{N}, 15^{\circ} 30^{\prime} 18.4^{\prime \prime} \mathrm{E}$, Duga Resa, the Mrežnica River upstream of the bridge in Duga Resa (Fig. 2), 29.8.2015;

$4-45^{\circ} 24^{\prime} 45.8^{\prime \prime} \mathrm{N}, 15^{\circ} 28^{\prime} 46.8^{\prime \prime} \mathrm{E}$, Mrežnički Brig, the Mrežnica River ca $500 \mathrm{~m}$ upstream of the bridge (Fig. 3), 30.8.2016;

$5-45^{\circ} 23^{\prime} 38.2^{\prime \prime} \mathrm{N}, 15^{\circ} 26^{\prime} 08^{\prime \prime} \mathrm{E}$, Zvečaj, the Mrežnica River by a bridge in Zvečaj, 4.7.2015;

$6-45^{\circ} 20^{\prime} 55.6^{\prime \prime} \mathrm{N}, 15^{\circ} 24^{\prime} 33.7^{\prime \prime} \mathrm{E}$, Dobrenići, the Mrežnica River near the bridge between Dobrenići and Keiči, 9.7.2016;

$7-45^{\circ} 15^{\prime} 17.8^{\prime \prime} \mathrm{N}, 15^{\circ} 24^{\prime} 44.9^{\prime \prime} \mathrm{E}$, Mrežnica, the confluence of the Mrežnica and Tounjčica rivers, 14.7 .2018 ;

$8-45^{\circ} 11^{\prime} 42.9^{\prime \prime} \mathrm{N}, 15^{\circ} 25^{\prime} 52^{\prime \prime} \mathrm{E}$, Tržić Tounjski, the Mrežnica River by a bridge of the road, 4.7.2015;

$9-45^{\circ} 10^{\prime} 27.4^{\prime \prime} \mathrm{N}, 15^{\circ} 27^{\prime} 03.6^{\prime \prime} \mathrm{E}$, Primišlje, the Mrežnica River to the west of Primišlje (Fig. 4), 12.7.2017;

\section{RESULTS}

In total, 29 aquatic molluscs (19 gastropods, 10 bivalves) were found at 9 sites of the Mrežnica River between the boundary of the Eugen Kvarternik military area and the confluence with the Korana River near Karlovac. A list of molluscs found at particular sites and an estimation of the density of their populations are shown in Tab.1. Theodoxus danubialis, Esperiana esperi, Microcolpia daudebartii, Holandriana holandrii were dominant at most sites and their numerous populations constituted the dominant component of molluscan biomass. Also Unio crassus, Pisidium amnicum and P. subtruncatum were recorded at most of the sites. Bithynia tentaculata, Lithoglyphus naticoides, Valvata piscinalis, Radix auricularia, Physa acuta, Unio pictorum, Anodonta anatina, Pisidium nitidum were found at 5 or 6 studied sites. Other species were found at from 1 to 4 sites. Changes in the molluscan communities are visible up-stream. The species Viviparus acerosus, Bithynia tentaculata, Valvata piscinalis, Pseudanodonta complanata and Pisidium henslowanum are more typical for the lower and medium river sections while Sadleriana fluminensis was found only in the upper river section.

Populations of three endangered or rare species (one gastropod and two bivalves) were found. Unio crassus was documented at all studied sites while Pseudanodonta complanata was recorded at 3 sites (site No. 2, 4 and 6). More numerous populations of $U$. crassus were found at sites No. 2 and 7. A few specimens were recorded at other sites, as with the case of P. complanata. An extensive population of the endangered gastropod Anisus vorticulus was found at the confluence of the Mrežnica and Tounjčica rivers (site No. 7).

Only one non-native mollusc was recorded; the North American Physa acuta occurs at 5 sites. 
Tab. 1. List of aquatic molluscs recorded at studied sites. $x$ - few specimens, $x x$ - scattered occurrence, $x x x$ - abundant occurrence.

\begin{tabular}{|c|c|c|c|c|c|c|c|c|c|}
\hline Species/Site No. & 1 & 2 & 3 & 4 & 5 & 6 & 7 & 8 & 9 \\
\hline Theodoxus danubialis (C. Pfeiffer, 1828) & $x x x$ & $x x x$ & $x x x$ & $\mathrm{xxx}$ & $x x x$ & $x x x$ & $x x x$ & $x x x$ & $\mathrm{x}$ \\
\hline Viviparus acerosus (Bourguignat, 1862) & $x x$ & & & & $\mathrm{xx}$ & & & & \\
\hline Esperiana esperi (A. Férussac, 1823) & $x x x$ & $x x x$ & $x x x$ & $x x x$ & $x x x$ & $x x x$ & $x x x$ & $x x$ & $\mathrm{xx}$ \\
\hline Microcolpia daudebartii (A. Férussac, 1823) & $\mathrm{xx}$ & $x x x$ & $x x x$ & $x x x$ & $x x x$ & $x x x$ & $x x x$ & $x x$ & $x x$ \\
\hline Holandriana holandrii (C. Pfeiffer, 1828) & $x x x$ & $x x x$ & $x x x$ & $x x x$ & $\mathrm{xx}$ & $\mathrm{xx}$ & $x x x$ & $x x$ & $x x x$ \\
\hline Bithynia tentaculata (Linnaeus, 1758) & $x x x$ & $x x x$ & $x x$ & $x x x$ & $\mathrm{xx}$ & $\mathrm{xx}$ & & & \\
\hline Sadleriana fluminensis (Küster, 1852) & & & & & & & $x x x$ & $x x x$ & \\
\hline Lithoglyphus naticoides (C. Pfeiffer, 1826) & & $x x x$ & $x x x$ & $\mathrm{x}$ & & $x x x$ & $\mathrm{xxx}$ & & $\mathrm{xx}$ \\
\hline Valvata cristata O. F. Müller, 1774 & & & $\mathrm{x}$ & & & & & & \\
\hline Valvata piscinalis (O. F. Müller, 1774) & $x x x$ & $x x x$ & $\mathrm{xx}$ & $\mathrm{x}$ & $\mathrm{xx}$ & $x x$ & & & \\
\hline Acroloxus lacustris (Linnaeus, 1758) & & & $\mathrm{x}$ & & $\mathrm{xx}$ & & & & \\
\hline Galba truncatula (O. F. Müller, 1774) & & & & & & & $\mathrm{x}$ & & \\
\hline Radix auricularia (Linnaeus, 1758) & $\mathrm{x}$ & & $\mathrm{x}$ & & & $\mathrm{x}$ & $\mathrm{x}$ & & $x$ \\
\hline Radix labiata (Rossmäessler, 1835) & & $\mathrm{x}$ & & & & & $\mathrm{xx}$ & $x x$ & $\mathrm{x}$ \\
\hline Lymnaea stagnalis (Linnaeus, 1758) & $\mathrm{x}$ & $\mathrm{x}$ & $\mathrm{x}$ & & & & & & \\
\hline Physa acuta (Draparnaud, 1805) & & $x x x$ & $\mathrm{x}$ & $x x$ & $\mathrm{xx}$ & $x x x$ & & & \\
\hline Anisus vorticulus (Troschel, 1834) & & & & & & & $x x x$ & & \\
\hline Gyraulus albus (O. F. Müller, 1774) & $\mathrm{x}$ & & $\mathrm{x}$ & & & $\mathrm{xx}$ & $\mathrm{xx}$ & & \\
\hline Hippeutis complanatus (Linnaeus, 1758) & & $\mathrm{x}$ & & $\mathrm{x}$ & & $\mathrm{x}$ & $\mathrm{x}$ & & \\
\hline Unio pictorum (Linnaeus, 1758) & $\mathrm{x}$ & $\mathrm{x}$ & $\mathrm{x}$ & $x x$ & $\mathrm{x}$ & $\mathrm{xx}$ & & & \\
\hline Unio crassus Philipsson, 1788 & $\mathrm{x}$ & $x x$ & $\mathrm{x}$ & $\mathrm{x}$ & $\mathrm{x}$ & $\mathrm{x}$ & $\mathrm{xx}$ & $\mathrm{x}$ & $\mathrm{x}$ \\
\hline Anodonta anatina (Linnaeus, 1758) & $\mathrm{x}$ & $\mathrm{x}$ & $\mathrm{x}$ & $\mathrm{x}$ & $\mathrm{x}$ & $\mathrm{x}$ & & & \\
\hline Pseudanodonta complanata (Rossmässler, 1835) & & $\mathrm{x}$ & & $\mathrm{x}$ & & $\mathrm{x}$ & & & \\
\hline Sphaerium corneum (Linnaeus, 1758) & $\mathrm{x}$ & $\mathrm{x}$ & $\mathrm{x}$ & & & $\mathrm{x}$ & & & \\
\hline Pisidium amnicum (O. F. Müller, 1774) & & & $\mathrm{x}$ & $\mathrm{x}$ & $\mathrm{x}$ & $\mathrm{x}$ & $\mathrm{x}$ & $\mathrm{x}$ & $\mathrm{x}$ \\
\hline Pisidium henslowanum (Sheppard, 1823) & $\mathrm{x}$ & $\mathrm{xx}$ & $\mathrm{x}$ & $\mathrm{x}$ & & & & & \\
\hline Pisidium milium Held, 1836 & & & & & & & $\mathrm{x}$ & & \\
\hline Pisidium nitidum Jenyns, 1832 & $\mathrm{xx}$ & $\mathrm{x}$ & $\mathrm{x}$ & $\mathrm{x}$ & $\mathrm{x}$ & & $\mathrm{xx}$ & & \\
\hline Pisidium subtruncatum Malm, 1855 & $\mathrm{x}$ & $\mathrm{xx}$ & $\mathrm{x}$ & $\mathrm{x}$ & $\mathrm{x}$ & $\mathrm{x}$ & $\mathrm{xx}$ & $\mathrm{x}$ & $\mathrm{x}$ \\
\hline Number of species & 17 & 19 & 21 & 17 & 15 & 18 & 17 & 9 & 10 \\
\hline
\end{tabular}




\section{DISCUSSION}

Rich molluscan assemblages inhabit the Mrežnica River except at the last two sites. As in the Korana River (Beran, 2013) the species Theodoxus danubialis, Esperiana esperi, Microcolpia daudebartii, Holandriana holandrii were dominant and their numerous populations constituted the dominant component of molluscan biomass. Molluscan assemblages of the two rivers are very similar. Altogether 32 species were found during research into the Korana River (BERAN, 2013) while the Mrežnica is inhabited by 29 species. A total of 26 species occurred in both rivers.

The occurrence of the endangered bivalve $U$. crassus which is declining in most European countries was confirmed and population seems to be more numerous than in the Korana River. The situation with the other endangered bivalve P. complanata is the same. This clam was found at three sites while in the Korana River its occurrence was confirmed only at Karlovac downstream of the confluence of the rivers (BERAN, 2013). While the existence of populations of $U$. crassus or $P$. complanata could be expected due to their occurrence in the Korana River the finding of an extensive population of $A$. vorticulus was surprising. An extinction or a decrease in its population density has been observed in most European countries (VAN DAmme, 2012) and this dramatic change led to the species being considered for inclusion in the EU Habitats Directive (Colling \& SCHRöDER, 2006). The nearest known sites at which it occurs in Croatia are Benča Lake in Vrana Lake Nature Park (Beran et al., 2013) and more sites are known from Krka National Park (BERAN, 2009, 2016). Its occurrence in the Mrežnica and Tounjčica rivers is very surprising because this species inhabits mostly various smaller water bodies in floodplains (TERRIER et al., 2006). On the other hand the species also occurs in lakes in the Krka National Park (Beran, 2009, 2016) and the confluence of the Mrežnica and Tounjčica rivers upstream of the waterfalls has a similar character. This species was confirmed from one site only but its occurrence at other sites can not be excluded and more detailed study of its occurence in the Mrežnica and Tounjčica rivers is needed.

Physa acuta is the only non-native species found in the Mrežnica River while in the Korana River three non-native species ( $P$. acuta, Ferrissia fragilis, Sinanodonta woodiana) were confirmed. $P$. acuta is common and widespread in Croatia and its occurrence is not surprising.

\section{ACKNOWLEDGEMENTS}

I am obliged to Helena Medková for preparing the map. I also thank to two anonymous reviewers for helpful comments.

Received January 25, 2019

\section{REFERENCES}

Beran, L., 2009: The first record of Anisus vorticulus (Troschel, 1834) (Gastropoda: Planorbidae) in Croatia? Malacologica Bohemoslovaca, 8, 70. Online serial at <http://mollusca.sav.sk> 14-December-2009.

Beran, L., 2013: Aquatic molluscan fauna (Mollusca) of the Korana River (Croatia). Nat. Croat., 22(2), 223-234. 
Beran, L., 2016: A contribution to knowledge of freshwater molluscs (Mollusca) of the Krka River in the Krka National Park (Croatia). Nat. Croat., 25(2), 295-304.

Beran, L., Lajtner, J. \& Crnčan, P., 2013: Aquatic molluscan fauna (Mollusca: Gastropoda, Bivalvia) of Vrana Lake Nature Park (Croatia). Nat. Croat., 22(1), 15-27.

Colling, M. \& Schröder, E., 2006. Anisus vorticulus (Troschel, 1834): In: Petersen B., Ellwanger G. (eds). Das europäische Schutzgebietssystem Natura 2000. Ökologie und Verbreitung von Arten der FFH Richtlinie in Deutschland, Band 3: Arten der EU Osterweiterung. Schrift. Landschaftspf. Naturschutz 69, 155-163.

Terrier, A., Castella, E., Falkner, G. \& Killeen, I.J., 2006: Species account for Anisus vorticulus (Troschel, 1834) (Gastropoda: Planorbidae), a species listed in annexes II and IV of the Habitats Directive. J. Conchol. 39, 193-205.

Van Damme, D., 2012: Anisus vorticulus. The IUCN Red List of Threatened Species 2012: e.T155966A738056.http://dx.doi.org/10.2305/IUCN.UK.2012-1.RLTS.T155966A738056.en. Downloaded on 22 December 2018.

\section{SUMMARY \\ Aquatic molluscs of the Mrežnica River}

\section{Beran}

This paper presents results of a malacological survey of the Mrežnica, the biggest tributary of the Korana River. Mrežnica has a natural character at the most of its course The river is frequently overgrown with aquatic macrophytes and the watercourse is interrupted with many waterfalls. Freshwater molluscs at 9 sites between the boundary of the Eugen Kvarternik military area and the inflow to the Korana River near Karlovac were studied from 2013 to 2018. Altogether 29 aquatic molluscs (19 gastropods, 10 bivalves) were found at 9 sites. Theodoxus danubialis, Esperiana esperi, Microcolpia daudebartii and Holandriana holandrii were dominant at most of the sites. The molluscan assemblages were very similar to the assemblages documented during previous research into the Korana River. Populations of three endangered or rare species (one gastropod and two bivalves) were found. Unio crassus was documented at all studied sites while Pseudanodonta complanata was recorded at 3 sites. An extensive population of the endangered gastropod Anisus vorticulus was found at the confluence of the Mrežnica and Tounjčica rivers. While the existence of populations of $U$. crassus and P. complanata could be expected due to their occurrence in the Korana River the finding of the extensive population of the rare gastropod A. vorticulus was surprising. Due to the occurrence of more numerous populations of three endangered molluscs the Mrežnica River looks to be more important than the Korana River of which it is a tributary. Only one nonnative mollusc Physa acuta was confirmed there. 
